\title{
Parenting and Youth Prosocial Behavior
}

\author{
Franky Simatupang \\ \{fsimatupang57@gmail.com\} \\ Postgraduate Program, Pelita Kebenaran School of Theology
}

\begin{abstract}
Prosocial behavior is a feeling of responsibility for problems faced by an individual in which the individual attempts to do something TO overcome the problems. This prosocial behavior does not develop automatically but requires a process of training or educating. And parenting plays an important role in the family. Emotional Quotient (EQ) is one aspect of intelligence in determining the effectiveness of using conventional intelligence. Monks explain intelligence is the ability to manage feelings, the ability to perceive, regarding these perceptions and determine one's potential to facilitate skills related to oneself, motivate, self-control, empathy and skill in building relationships with others
\end{abstract}

Keywords: Parental Parenting, Prosocial Behavior, Youth

\section{Introduction}

Every individual has social relationships with other people or particular groups and interact in a time of need. This condition is called prosocialbehavior. Prosocial behavior is a feeling of responsibility for problems faced by an individual where the individual attempts to do something overcome the problems. This prosocial behavior does not develop automatically but requires a process of training or educating(Alma, 2010), whileparenting plays an important role in the family. Parenting is a reflection of everyday life of parents on their children,even until adulthood in a family. In parenting, various models are used in the family, one of which is authoritative (Musaheri, 2007). Every parent has a different parenting style in each family, according to the personality characteristics and character of the parent. For example, authoritarian parenting tends towards strictness, always rigid and restraining on children. If parenting is applied in the family, especially for children, it will be easy for children to become stressful, frown, not easy to be friendly to others, even affecting their psychological development and social condition until the child grows up. And the fact is parenting greatly influenced children's emotional intelligence.

Emotional Quotient (EQ) is one aspect of intelligence that determines the effectiveness of using conventional intelligence. Monks explain that emotional intelligence is the ability to manage feelings, the ability to perceive,the ability to act based on these perceptions and determine one's potential to learn practical skills that are based on self-awareness, motivation, self control, empathy and skills in developing relationships with others (Yantiek, 2014). At intermediate-school age or adolescence, also known as the period of crisisor a periodsearching for identity, teenagers are no longer included in the group of children, but not yetfully accepted in adult groups. At the age of adolescence it is very easy to be influenced by the environment, consequently there will be disappointment, misery, the increase of conflict, challenges and opposition, dreams and fantasies, courtship andromance, alienation from adult 
life and cultural norms. At this time also children can already determine which is good and bad, and to think logically (M. Ali Asrori, 2011).

According to the Indonesian Child Protection Commission 'Komisi Perlindungan Anak Indonesia' (KPAI, 2012) the nation and all relevant partiesmust work harder to save abandoned childrenor overcome various other problems. The reason, in fact is the number of children affected by a parenting problemis very large, reaching 4.1 million people. Among them are 5,900 children being victimsof violence, 34,000 street children, 3,600 children having problems with the law.Cases that become new problems related to child care are increase every year. Responsibility and development of behavior of childrenare in the hands of the parents. Head of Police Public Relations Division, Metro Jaya MetropolitanResort, South Jakarta Sector Tebet, Sr. Comr. DedeKurniawan, there are 18 cases of resistance /brawl, 35 cases of assault, 29 cases of theft, 3 cases of unpleasant treatment, 8 cases of minor assault, and 33 drug cases. Most children and adolescents are involved in violations come from families with lack of care or do not care at all towards the school environment and family.

From those studies it is understood that there is a connection and correlation between parenting, emotional intelligence and prosocialbehavior or social care. Parentinglargely affects social care, while social care can be seen from the application of parenting by parents because children with high emotional intelligence will have high social responsibility. On the other hand, children with low emotional intelligence have low levels of social care.

\section{Research Methodology}

This research was conducted in $8^{\text {th }}$ grade of the State Middle School 238 Duren Tiga, Pancoran, JakartaSouth, during January 2016 to July 2016. The study population was all studentsclass VIII of the 238th State Junior High School in Jakarta numbered 209 students, while the research sample was takenwith simple random sampling method with 137 students. Data collection was done by observation, documentation and questionnaire. The data analysis program was descriptive, prerequisite, and tested hypotheses with the help of Microsoft Office Excel 2013. The results of the chi-square normality test were normally distributed. The correlation coefficient of Product Moment produces rxy $=0.471$.

\section{Results And Discussion}

Based on the research, the adolescents of eight grade, State Junior High School 238Duren Tiga Jakarta was scored as 0.471 and $r$-tabel of 0.168 . It can be concluded that $r$ count 0.471 is more than r-table 0.168 , it can be concluded that there is a positive relationship between parenting parents and the social care of teenagers at State Junior High School 238 Jakarta. The results of the discussion fall into the category of moderately strong or moderate. And it is known that $\mathrm{t}$ count is $6.207>\mathrm{t}$ table is 1.978 , so it can be concluded that there is a significant positive relationship between parenting parents and adolescent social care. Judging from the relationship between parenting style and the social care of the eighth grade students of State Junior High School 238 Jakarta only reached 22\% and the remaining 78\% was determined by other factors such as peers, role models, vision intelligence, and so on. The way parents provide definitions of social care to children is important in order for children to have high social values. Furthermore, according to Alma (2010),the familyisthe smallest social environment experienced by humans. This is the environment where people first experience 
interaction. It is important to note that the family environment that introduces the first social feeling. For example, a child can develop feelings of sympathy towards parents, as they see that they are receiving proper care. From that condition a feeling of love will emerge from children to parents and other family members, thus there will be mutual caring.

Alma, et al (2010) share forms of concern, namely:

1. In the Family Environment, Family is a social environment that is attended by humans. This is the environment that first spoke with humans. People should live in a family to find happiness. But what he expected was not always in line with expectations. The most important thing to note is that the home environment will support the development of the first social feeling.

2. In the Social Environment, The environment of rural communities that still have strong traditions still maintains an attitudevery close social care. Activities carried out by onefamily, then other families without imbalances will immediately help with varietyway. For example, when you want to announce a house, other family members take timeto try to help him.

3. In the School Environment, Schools are not only a place to learn to improve intellectual abilities, but it also helps children to be able to develop logical, cultured, moral,community, and physical abilities. Ahmadi\&Uhbiyati (2001) explain that, the function of the school as a social institution creates social humans who can get alongwith fellow humanseconomy, differences in religion, race, civilization, language and so on.

\section{Conclusion}

Based on descriptive analysis, statistical data processing and data analysisdescribed earlier then conclusions can be drawn as follows:

1. Based on the scores of each respondent, parenting parents of eighth gradeState Junior High School students238 Duren Tiga Jakarta has the dominant dimension. The dimension that has the highest percentage with authoritarian parenting dimensions(77\%), democratic parenting dimension( $75 \%)$ and the smallest ispermissive parenting dimensions $(52 \%)$.

2. Based on the scores of each respondent, the social care of eighth grade State Junior High School 238 Jakarta studentshas the dominant dimension or dimension that has the largest percentagenamely the dimension of understanding and empathy by $85 \%$, the dimension of consciousness for interactionby $77 \%$ and the dimension of the ability to run is $60 \%$.

3. R score was 0.471 and $r$ table of 0.168 . Based on these results, the $r$ count is greater than $r$ table $(0.471>0.168)$. So there is a positive relationship between parenting parents and adolescent social care. These results are interpreted with a table of criteria for strengthening coefficients and included in the category of moderately strong or moderate.

4. The calculation of " $\mathrm{t}$ " test to calculate the count of 6.207 and t table 1.978. Thus $t$ count is greater than t table $(6,207>1,978)$. This shows that the second variable has a significant positive relationship.

5. The calculation of the determination coefficient of $22 \%$ shows that the social care of adolescents of eighth gradeState Junior High School 238 Jakartais determined by parenting style, while $78 \%$ is determined by other factors, such as peers, role models, emotional motivation and so on.

6. The hypothesis test of relationship of parenting parents with social careGrade VIII teenagers at State Junior High School 238 Jakarta showed a positive relationshipbetween both. 